\title{
Three Waterborne Epigrams: Archimelus, Callimachus, Catullus
}

\section{Introduction}

Texts are self-evidently material things; the etymology implies as much, suggesting that the text is something 'woven'. And yet the very fact that the materiality of texts is the subject of scholarly enquiry indicates that there is something about the written word which exceeds its own materiality. Reading endows words with a depth incommensurate with the superficiality of marks on a page. In turning our attention to the materiality of texts, then, we are attempting to undo the excavatory work of reading and bring the inscribed surface back into focus. But the materiality of texts is not only skin deep, and texts conceal further material strata beyond the matter of the page. This is perhaps most obvious in the case of 'book-epigrams', the accepted term for poems which have somehow escaped from stone to papyrus, thereafter maintaining a relation to inscriptionality which is tropological or aetiological rather than substantial.

In this paper, I would like to attempt to expand the possibilities of mapping this relation between book-epigram and inscription. I suggest that the trope of inscription in book-epigram has the potential to open up a space of transference between the materiality of the text and the materiality of non-textual bodies, whether natural or artificial, animate or inanimate. In order to explore this, I will look at three poems which are closely concerned with boats or other seagoing vessels: Supplementum Hellenisticum (SH) 202 Archimelus, Callimachus Epigr. 4 Praef., and Catullus 4. Each of these vessels comes to be figured variously as a viewed object, an inscribed surface, and the source of the poem's speaking voice, without ever ceasing to be a watercraft. Taken as a group, I suggest, these poems represent an experiment in expanding the material imaginary of book-epigrams. By taking epigram out to sea, these poems make possible novel ways of conceptualising the material bond between epigrams and the objects they inscribe and describe.

\section{SH 202 Archimelus (Ath. 5,209c)}

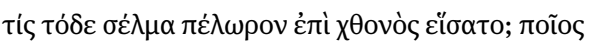

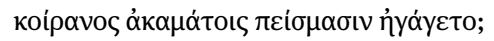

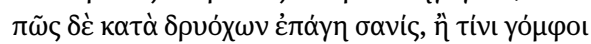

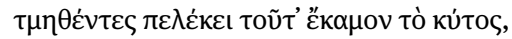

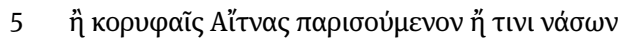

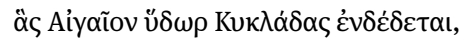




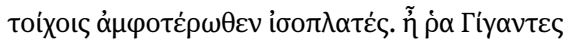

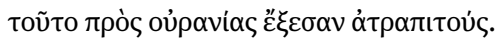

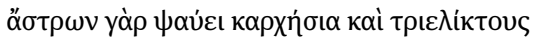

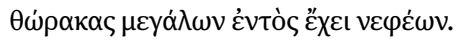

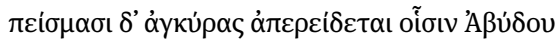

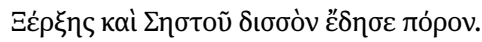

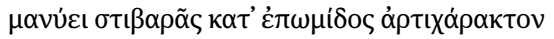

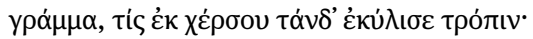

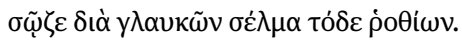

Who set this gigantic ship on the earth? What great lord hauled it with untiring cables? How was the ribbing fixed to the frame? With what axe were the bolts carved that worked this hold, as high as the peaks of Aetna or one of the Cycladic islands which Aegean water encircles, its circumference as wide as walls? Surely the Giants carved it to reach the paths of heaven: its masthead touches the stars and it hides its bulwarks in the mighty clouds; its anchors are fastened with the cables with which Xerxes secured the dual passage between Abydus and Sestus. An inscription freshly engraved upon its sturdy prow reveals who rolled out this vessel from dry land: it says "Hieron, son of Hierocles, the Dorian sovereign of Sicily, bearing gifts of rich produce to all Hellas and her islands." Come, Poseidon, preserve this ship amid the seething waves. ${ }^{1}$

(SH 202 Archimelus (Ath. 5,209c))

This epigram, the only known work of its author, is preserved by Athenaeus as part of his account of the great luxury vessel built by Hieron II of Syracuse. The poem takes the part of a curious bystander who sees the mighty ship for the first time and wonders how such a marvel could have been constructed. The encounter that Archimelus' epigram stages between the spectator and Hieron's ship has a narrative structure which can be taken as emblematic for all epigram with some relation to inscriptionality. The anonymous passerby is confronted with the sight of a monumental object-a gravestone, a votive stele, a statue, etc.-and consults the inscription for the information necessary to explain this object: who made it and why, or who lies buried beneath it. This sequence of viewing followed by reading, a question followed by an answer, can be termed the epigrammatic encounter. ${ }^{2}$ Archimelus' epigram can be called 'ecphrastic' in that it folds the act of viewing into the narrative frame of the poem; instead of simply offering the answer to an implied question as an inscriptional epigram might do, this poem stages the encounter itself through a series of interrogatives. ${ }^{3}$

But Archimelus departs from the usual model of ecphrastic epigram in one crucial point. At the climax of the poem, our viewer's questions are answered when his eyes light upon an inscription on the ship, which he quotes (13-18). This quoted inscription

1 All translations are my own.

2 On questions in epigram, see e. g. Bruss 2010, 391-392.

3 Gutzwiller 2002, 171-174. 
is a striking example of 'mise-en-abyme'; embedded within the drama of the viewer's encounter with the ship is the encounter with an epigram which relays the encomiastic content of Archimelus' own epigram, namely, the title and attributes of his pa-

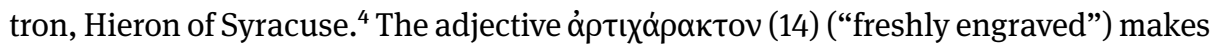
us attend to the materiality of the very letters as part of the visual spectacle of the ship; but when Archimelus relays the text of the inscription, he incorporates its material within the body of his poem.

This physical fusion between Archimelus' epigram and the inscription on the ship finds expression in the deictic pronouns which the poet uses to refer to the vessel: in

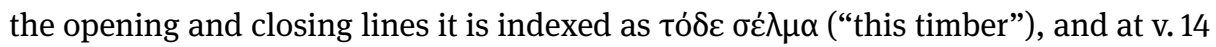

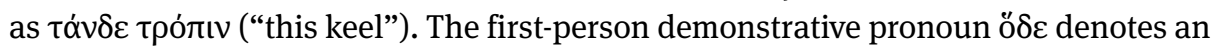
object that is close at hand to the speaker, and it is routinely employed in inscriptions to refer to the inscribed object. ${ }^{5}$ Accordingly, when the poem turns from quoting the inscription to intoning a prayer to Poseidon to "preserve this timber amid the seething

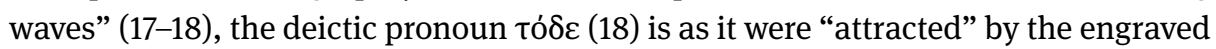
letters, so that Archimelus' prayer is notionally appended to the inscription on the ship itself.

This catachresis of the inscription is motivated by more than poetic fancy, however. Athenaeus' account of the epigram's historical occasion provides the necessary background:

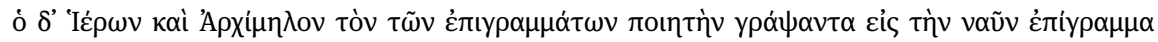

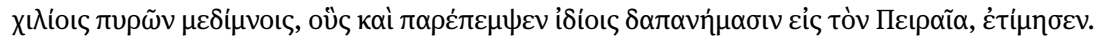

Archimelus, the poet of epigrams, wrote an epigram on the ship, and Hieron rewarded him with a thousand medimnoi of wheat, which he sent at his own expense to Piraeus.

(Athen. 5,209c)

If Athenaeus is correct, then Archimelus' mention of gifts of grain sent to all the Greek islands does not only celebrate the ship's impressive carrying capacity, it also commemorates the poet's compensation for this very epigram. If this is so, then the encomiastic epithet $\delta \omega \rho о \varphi о \rho \tilde{\omega} v$ ("gift-bearing") (16) underscores the element of gift-exchange in the relationship between Archimelus and Hieron: Hieron's medium of gift-giving is sea transport, Archimelus' is poetry. But Hieron's ship does not only bear gifts of grain; it also bears the inscription which records its master's name, spreading his $\kappa \lambda \varepsilon$ ć or renown throughout the Greek world. When Archimelus offers a prayer for the safe passage of the vessel, then, he is implicitly praying for the continuance of his

4 Cf. Hardie 1983, 129-130, who compares AP 7,465 (Heracleitus).

5 Svenbro 1993, 26-43. 


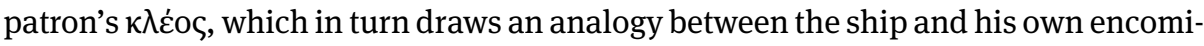
astic poetry: both are powerful long-range transmitters of $\kappa \lambda \varepsilon \dot{\delta}$. ${ }^{6}$

The relation that binds Archimelus' poem to Hieron's ship is more than metaphorical, however; it is also economic, and hence material. The ship is in a very real way the matter of Archimelus' epigram, to the extent that the poem could not exist without it. But Archimelus was apparently not satisfied with merely writing an epigram on the ship, where "on" means "on the subject of". 7 The poem's self-reflexive use of the embedded inscription ensures that the poem is also in a sense physically on the ship, so that the vessel is not only the matter but also the medium of the epigram. These two senses of the English preposition on correspond to epigram's two primary modes of engagement with objects: epigrams can provide an external view on an object, through description or anecdote, or they can inscribe themselves on an object's surface, uniting with its material form. This epigram shows where these two modes intersect, where description shades into inscription.

Adopting a seaworthy boat as the inscribed surface for an epigram is an unconventional choice for the simple reason that a boat, unlike an ex voto or funeral monument, is a moving object. Consider, by way of comparison, the well-worn trope whereby votive or sepulchral epigrams address themselves to a passerby, entreating her to pause on her way to read the inscription and honour the memorial. ${ }^{8}$ Roadside epigrams such as this present themselves as interruptions in the flow of daily life, unplanned occasions for a brief encounter with mortality or the divine. The human life or the votive transaction they monumentalise is by definition a fait accompli, and accordingly epigram is, again by definition, the last word on the subject. The monument marks the end of time for its subject, but it also stops time briefly for its viewer. The immobility of stone, paired with the injunction to "stop and read", is a material manifestation of the experiential association between recollection and pausing. The space of the epigrammatic encounter is thus pre-eminently a liminal space in which the forward trajectory of experience is momentarily suspended. ${ }^{9}$

6 Theoc. 16,98-100 also uses the metaphor of sea travel in connexion with Hieron's $\kappa \lambda \varepsilon \dot{0}$. . Hardie 1983, 130 surmises that Archimelus' poem was written to commemorate the dedication of the ship, but there is one other possibility: Athenaeus records that Hieron later gifted his ship to Ptolemy, and the epigram would not be entirely out of place as a dramatisation of the gift's arrival on Egyptian shores. 7 Athenaeus uses the preposition cic, which is also the preposition used e.g. in the proem to the fourth book of the Planudean Anthology to designate epigrams 'on' or 'in celebration of' a subject, without specifying whether the epigram was actually inscribed thereon (c. f. Lauxtermann 1998, 528). 8 On the passerby in epigram see Tueller 2010.

9 Frye 1985, 31-32 links discontinuity to the 'lyric' mode in general: "In the lyric, [...] we turn away from our ordinary continuous experience in space or time [...] The discontinuous element in poetry is often linked to a specific, usually ritual, occasion, and the element of occasion means that the poem revolves around that occasion, instead of continuing indefinitely. [...] The private poem often takes off from something that blocks normal activity, something a poet has to write poetry about instead of carrying on with ordinary experience." 
Hieron's ship, by contrast, is a monumental achievement in the extension of human mobility. Archimelus makes it into a dream-machine capable of carving a path to the stars (7-8). In one of his more memorable hyperboles, he surmises that the ship not only affords passage between stretches of land like a bridge, but is actually made of bridges, namely the pontoon bridges Xerxes famously built to cross the Hellespont (11-12). The very material properties which make the ship a wonder to behold, its spectacular size and its spectacular mobility, also disqualify it from the class of objects that can be "passed by" in the manner of a wayside inscription. Using Hieron's ship as an inscribed surface therefore radically alters the relationship between inscription and reader. This is reflected in the prayer at the poem's end: "Poseidon, preserve this ship amid the seething waves" (17-18). As always in inscribed epigram, the closing prayer acts as an envoi, marking the passerby's departure from the monument; here, however, it is the ship that will pass away from the viewer rather than the other way round.

We have already noted that, in praying for the "preservation" of the ship on its future voyages, the speaker is effectively praying for the preservation of the message that it bears in the form of its inscription, and hence, by extension, for the preservation of Hieron's $\kappa \lambda \varepsilon \dot{\varepsilon}$. . This represents something of a departure from traditional conceptions of the transmission of $\kappa \lambda$ ćoc. Pindar famously boasts in the fifth Nemean ode that his epinician song is a greater tribute than a statue because it does not "stand idle on its base" but can travel by ship to announce athletic victories to inhabitants of other islands. ${ }^{10}$ In Pindar's passage, the $k \lambda \varepsilon$ ć or news of the victory is conceptualised as cargo, which can be transported on the vehicle of his poetry; this is an example of what cognitive linguists refer to as the 'conduit metaphor' of verbal communication. According to this standard conceptual metaphor, verbal messages are like 'containers' or 'parcels' which the sender packs with meaning and transmits to the receiver to be 'unpacked'. ${ }^{11}$

Unlike Pindar's freighters, however, Hieron's ship is not a conduit or vehicle of

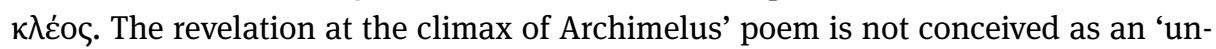
packing' of the meaning hidden within the spectacle of the ship; if it were, the poet would have said something to the effect of "only one so mighty as Hieron could have built this ship". Instead, the encounter with the $\kappa \lambda \varepsilon$ ć of Hieron is an encounter with the freshly engraved letters that adorn its dazzling surface. The act of 'reading' the ship's surface is not an act of interpretation, but only of recitation: the viewer simply

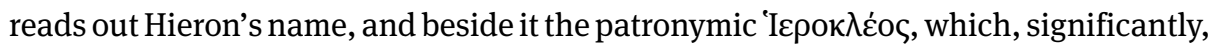
contains the very word $\kappa \lambda \varepsilon \dot{\varepsilon}$ ○ within it. By wearing its message on its sleeve-literally

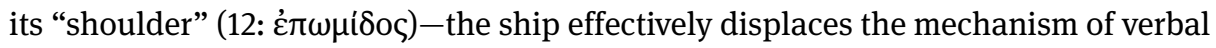

10 Pi. N. 5,1-3.

11 Reddy 1979. 
communication, which normally governs the transmission of $k \lambda \varepsilon$ ć, , reducing it to the bare materiality of the letter, transposed onto its own material form.

With this discussion of $\kappa \lambda \varepsilon$ ć inscription and voice. Svenbro in his influential monograph on Greek conceptions of reading ties $\kappa \lambda$ ćos intimately to the production of voice: inscriptions, he argues, have no voice of their own, but when the passerby reads one aloud, she lends her vocal apparatus to serve as its instrument. ${ }^{12}$ This union between the reader and the inscription produces $\kappa \lambda \varepsilon$ ć, , which Svenbro memorably defines as "acoustic renown", ${ }^{13}$ and which alone can confer a "sonorous reality" on the silent markings of the inscription. "The inscription", he concludes, "is a machine designed to produce kléos."15

On Svenbro's view, the human element is the animating principle of $\kappa \lambda \dot{\varepsilon}$ oৎ in part because the living voice belongs to a living person who can recall and relay the message of the mute inscription long after she has passed it by. For this reason, he argues that no inscribed object has a voice of its own even if it speaks in the first person. ${ }^{16}$ The belief that objects can speak because they have somehow been invested with the property of voice entails an "animism" or "vitalism" which, Svenbro argues, was foreign to the Greeks, to whom he attributes a more mechanistic and materialist theory of voice. ${ }^{17}$ This very opposition between two conceptions of voice-voice as vital principle and voice as mechanical effect-lurks beneath the surface of our next epigram, Callimachus' poem on the nautilus.

\section{Callimachus Epigr. 5 Praef. = 14 G.-P. (Ath. 7,318b)}

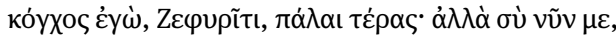

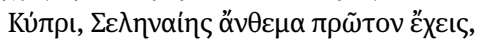

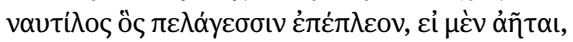

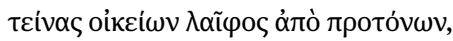

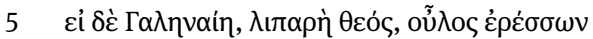

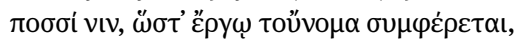

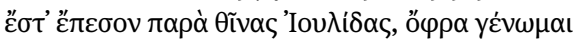

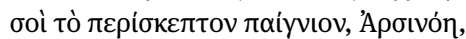

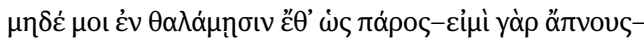

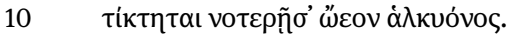

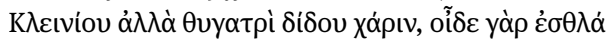

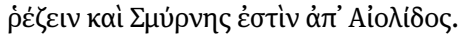

12 Svenbro 1993, 26-43.

13 Svenbro 1993, 164.

14 Svenbro 1993, 62.

15 Svenbro 1993, 62.

16 Svenbro 1993, 41-43.

17 Svenbro 1993, 42. 
I, O Lady of Zephyrium, am a conch shell, once a wonder to behold; but now I am in your possession, Cypris, as the first dedication of Selenaea, I the nautilus who used to sail the seas, opening my sail from my own forestays if there was wind, but in Fair Weather, that sleek goddess, relying solely on paddling with my legs-see how my name aligns with my work!-until I beached on the shore of Ioulis, so that I might become your much-admired plaything, Arsinoe, and no longerfor I am breathless-is the egg of the aquatic kingfisher laid in my chambers. Well then, give thanks to Clinius' daughter, for she knows how to do what is right, and she hails from Aeolian Smyrna.

(Callimachus Epigr. 5 Praef. = 14 G.-P. (Ath. 7,318b))

This is a votive epigram on a nautilus shell dedicated at the temple of Aphrodite of Zephyrium, complete with a zoological excursus on the nautilus itself. Like Hieron's ship, the nautilus is a moving object, and, according to the Aristotelian account which likely informed Callimachus' zoological insights, ${ }^{18}$ its locomotion is akin to that of a boat; hence the name vavtỉoc. Unlike Hieron's ship, however, the nautilus is figured as the speaking subject of the poem. The nautilus relates not only the story of its dedication to the goddess, but also the story of its former life on the sea: it once sailed about as it pleased and housed the eggs of the kingfisher within its cavities, but now it is only an "admired toy" for the goddess' pleasure. Dedication is death for the nautilus, and therefore this votive epigram is also its funeral monument; but the moment of the nautilus' death is also the moment of its transformation into an inanimate object in the form of its empty shell, an object, which can also serve as an inscribed surface.

Lest we forget that the empty shell is in fact a corpse, the nautilus takes the time to spell out the fact of its death for us-only it does not use a typical word for 'dead'.

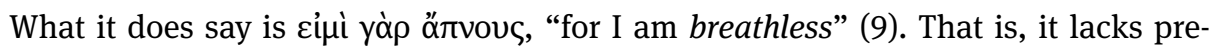
cisely the medium which previously allowed it to sail on the open sea, but also the medium of speech. On one level, this statement ironically destabilises the claim to voice implied by the speaking-object fiction. However, the nautilus-shell is not a typical speaking object. The speaking-object fiction normally confers speech either on inanimate objects, which cannot speak by definition, or on funeral monuments which ventriloquise a human corpse, which could once speak but can no longer. The nautilus shell floats somewhere between these categories: it is in one sense an inanimate object and in another sense the corpse of a living creature; it once lived but could not speak even when alive. ${ }^{19}$ The shell's ambiguous vitality is expressed in the ambiguous term örvouৎ, which leaves open the distinction between the dead and the inanimate, so that we cannot be sure whether it has lost its 'breath' or never had it to begin with.

18 On the relationship of this poem to the descriptions of the nautilus at Arist. HA 525a22-25 and 622b5-15, see Gutzwiller 2002, 196-197.

19 As Aristotle argues at De Anima 421a3-6, fish (and presumably other aquatic animals) have no voice because they have no pharynx and therefore no breath. See Butler 2015, 31-58 for more on Aristotle's theory of voice. 
But there is one further aspect of vitality in Callimachus' nautilus. Not only can it not sail on the open sea in its current form, it can also no longer house the eggs of the kingfisher in its inner recesses. Gutzwiller argues that this detail reflects the probable votive context of the epigram: the dedicator, Selenaea, would likely have been a young woman approaching marriage, and the dedication to Aphrodite would have accompanied prayers for "smooth sailing" in love. ${ }^{20}$ The nautilus' yearning for the eggs it used to store thus oddly recapitulates the maiden's desire for offspring, an association strengthened by the word used for the nautilus' cavities, $\theta \alpha \lambda \alpha \mu \eta$ ' the common word for 'bridal chamber' ( $\theta \dot{\alpha} \lambda \alpha \mu \circ)$ ). Unlike the young bride-to-be, however, the nautilus is not truly a mother, only a vessel. The nautilus' relation to the eggs of the kingfisher is in fact curiously analogous to its relation to the breath, and hence the voice, which it lacks: though the nautilus speaks of its voice as something which was once part of its vital substance and which is now lost in death, we know that it only speaks by virtue of the words inscribed on its shell. By conjuring up the fiction of an inner life which can be recounted and reminisced on, the shell entertains the pretense that the words scrawled on its inanimate surface are actually emanating from somewhere within its hidden depths.

The shell's pretense of interiority is belied by the admission that it has now be-

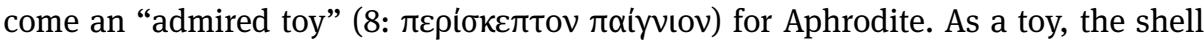
invites play, and the kind of play that the epigram envisions is signalled by the ad-

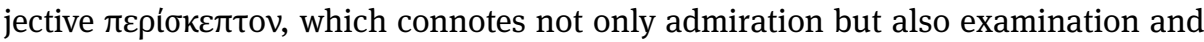
speculation. ${ }^{21}$ In Homer, a $\pi \varepsilon \rho i ́ \sigma \kappa \varepsilon \pi \tau о \varsigma ~ \chi \tilde{\omega} \rho \circ \varsigma$ is an elevated place that offers a wide surrounding view, ${ }^{22}$ so the adjective represents the shell as an open book, which divulges all its secrets to the viewer. Like the viewer of Hieron's ship, the viewer of the shell plays with it by probing it with an inquisitive gaze, asking questions about it, and perhaps reconstructing its life story, just as Callimachus' epigram does. Thus the

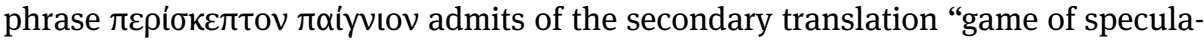
tion", an apt phrase for capturing the way that the epigram itself 'plays' with the shell and its inscribed voice.

This phrase effectively gives the game away, reminding us that even as we entertain the fiction that the nautilus is speaking, all we are really doing is scanning the perimeter of its shell. Despite all its protestations, this erstwhile nautilus, much like Hieron's ship, is not an eloquent parcel pregnant with communicable meaning; it has no content, no tale to tell. At the same time, however, if voice is nothing more than a manipulation of air, then the nautilus shell is paradoxically more receptive to voice and voicing now that it is vacant. A shell, unlike a shellfish, can be held to the ear to hear the voice of the sea. Similarly, now that the nautilus is dead and departed, we can

20 Gutzwiller 1996.

21 лврьбколє́ $\omega$ can mean 'examine' (Liddell-Scott-Jones def. II) or 'speculate' (Liddell-Scott-Jones def. II.2, citing Sophocles Ichneutae 737).

22 Hom. Od. 1,426; 10,211. 
speak for it in a way it never could by telling its story. Given this fact, I wonder if we would be mistaken in hearing the hollow sound of the conch horn in the shell's first

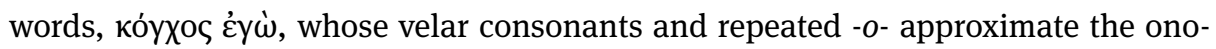
matopoeia in words like English coconut, cuckoo, conk. Perhaps in one sense it is that very property of airy emptiness, which makes our nautilus so apt for vocalisation. ${ }^{23}$

\section{Catull. 4}

This brings us to our final poem, one of the most celebrated instances of lending voice to watercraft in ancient literature: Catullus' poem on the phaselus, the bean-podshaped yacht which conveyed its master from Bithynia to Italy.

Phaselus ille, quem videtis, hospites, ait fuisse navium celerrimus, neque ullius natantis impetum trabis nequisse praeterire, sive palmulis

5 opus foret volare sive linteo. Et hoc negat minacis Hadriatici negare litus insulasve Cycladas Rhodumque nobilem horridamque Thraciam ${ }^{24}$ Propontida trucemve Ponticum sinum,

10 ubi iste post phaselus antea fuit comata silva; nam Cytorio in iugo loquente saepe sibilum edidit coma. Amastri Pontica et Cytore buxifer, tibi haec fuisse et esse cognitissima

15 ait phaselus: ultima ex origine tuo stetisse dicit in cacumine, tuo imbuisse palmulas in aequore, et inde tot per impotentia freta erum tulisse, laeva sive dextera

20 vocaret aura, sive utrumque Iuppiter simul secundus incidisset in pedem; neque ulla vota litoralibus deis sibi esse facta, cum veniret a mari novissimo hunc ad usque limpidum lacum.

25 Sed haec prius fuere: nunc recondita senet quiete seque dedicat tibi, gemelle Castor et gemelle Castoris.

23 Cf. Holmes, "The Chambered Nautilus" vv. 25-26 (Powley 1931, 49-50): "From thy dead lips a clearer note is born / Than ever Triton blew from wreathèd horn!”.

24 Thomson conjectures Thracia here; I read Thraciam with the MSS. 
The bean-shaped boat which you are looking at, strangers, claims that he was once the fastest of ships, and that no other floating timber could surpass his speed, whether there were need to fly with oars or with sail. He declares moreover that the shore of the menacing Adriatic does not deny this, nor the Cycladic isles, noble Rhodes or bristling Thrace, the Propontis or the treacherous Pontic bay, where the boat-to-be was once a long-haired forest; for high on Mt. Cytorus he often let out a whistle from within his talkative hair. The boat claims that this was and still is well known to you, O Pontic Amastris and wooded Mt. Cytorus: he tells how from the very beginning he stood atop your summit, dipped his oar-hands in your water, and went on to bear his master through countless violent rapids, whether the breeze called him to starboard or to port, or else Jupiter fell upon his stern from both sides at once; and no vows were made by him to the gods of the shore up until he arrived at the last from the sea to this limpid lake. But that was all in the past: now he grows old in peaceful seclusion and dedicates himself to you, twin Castor and Castor's twin.

(Catull.4)

Catullus' poem closely echoes a number of the features of Callimachus' nautilus epigram: each craft gives an account of its previous journeys leading up to the present moment of dedication, setting up a thematic opposition between the vivacity of its former life and its present state of inaction, and destabilising the dichotomy which associates voice with vitality and voicelessness with death. While the phaselus is presented as a speaking object, however, it is not the speaking subject of the poem. Rather, Catullus stages the encounter with the boat within a framework of triangulated reportage: the first-person speaker relays the speech of the boat in indirect discourse to an audience of hospites, "guests" or "strangers", who evidently can only see the vessel, not hear its voice.

The mediation of the first-person speaker means that the encounter with the boat is an encounter with a voice, not an inscription, and the poem's iambic trimeter is not a metre normally associated with epigram. At the same time, however, the opening address to hospites takes up the inscriptional master-trope of the address to the passerby. This fact has encouraged Courtney to understand the mediator as in fact reading out an inscription on the boat itself, which would closely parallel the situation of Archimelus' epigram. ${ }^{25}$ I will come back to this presently, but for now it will suffice to note that vocality and inscriptionality sit together uneasily in this poem. Most strikingly, in relaying the boat's account of its life story, the mediator records more than the content of the boat's narrative: he also ends up capturing something of its idiom. Fitzgerald and Davis both convincingly argue that the mediator parodies the boat's comical style of speech, which has been variously described as garrulous, breathless, singsong, Greek-accented, and Asiatic, with stylistic idiosyncracies which deviate wildly from Catullus' normal iambic register. ${ }^{26}$

25 Courtney 1997.

26 Fitzgerald 1995, 104-110; Davis 2002. 
Given the question of inscription and voice raised above, however, I would reframe the matter somewhat to address the problem of how the boat comes to have the power of speech in the first place. This poem, I suggest, serves as an eloquent exemplar of what Shane Butler calls the "phonographic claim" of ancient literature, ${ }^{27}$ which he defines as the avowed capacity of literary texts in antiquity "to capture the voice precisely as something conceptually distinct from language, even if largely inseparable from it." ${ }^{28}$ Only this poem does more than capture the voice; it uses that captured voice to recount a fable of its very capture. Like the nautilus epigram, Catullus' poem plays on the dual function of air as both the medium of the boat's conveyance and the medium of speech. Boasting of its quick manoeuvring, the phaselus claims that it would react promptly "whether the breeze called it to starboard or to port" (19-20), suggesting that its sails respond to the wind as faithfully and expediently as a slave responds to her master's voice. But the wind also plays a role in the story of the boat's early life in the Pontic bay, where, Catullus relates, "the boat-to-be was once a long-haired forest; for high on Mt. Cytorus he often let out a whistle from within his talkative hair" (10-12: iste post phaselus antea fuit / comata silva; nam Cytorio in iugo / loquente saepe sibilum edidit coma).

The talkative hair of the forest that yielded the timber for Catullus' phaselus boasts a venerable literary pedigree. It has become standard to note that the boat's adventures parallel the path of the Argonauts, making the phaselus a kind of latter-day Argo, ${ }^{29}$ but it is less often remarked that the two vessels also have in common the faculty of speech. ${ }^{30}$ A number of the surviving Argonautic narratives records the detail that the Argo was built from the timber of the sacred oak of Zeus at Dodona, which was thought to have the power of prophecy, and that owing to its supernatural material, the boat itself had the capacity to utter prophetic warnings to its crew at critical moments. ${ }^{31}$ The two earliest accounts of the oracle of Zeus at Dodona are in the Iliad and Odyssey, and each passage presents a different conception of the role of the sacred oak in the transmission of the oracles. In the Iliadic passage, the oracle is attended by mysterious priests called Selloi who are designated the god's "interpreters" (Hom. Il.

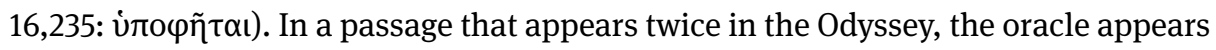
to come from the oak itself:

\footnotetext{
27 Butler 2015, 13-14.

28 Butler 2015, 12.

29 See most recently Massaro 2010.

30 Mette 1963.

31 The Argo speaks at A. R. 1,524-527 and 4,580-583, which the poet explains is made possible by the

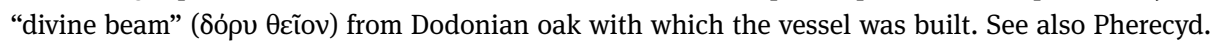
Historicus fr. 111 (= Apollod. Mythographica 1,9,19); Orph. A. 1159-1169; Val. Fl.1,300-310 (and cf. the epithet in 1,2: fatidicam ratem).
} 


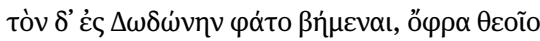

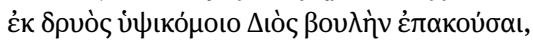

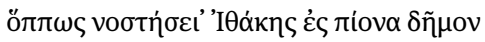

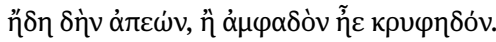

But as for him [Odysseus], he [Pheidon] said that he had gone to Dodona to listen to the counsel of Zeus from the high-haired oak of the god, so that he might return home to the fertile land of Ithaca after his long absence, whether openly or in secret.

(Hom. Od. 14,327-330 and 19,296-299)

Taken together, these passages seem to attest to a practice whereby priests acted as the intermediaries for oracles issuing from the oak tree itself, as if from a kind of inner voice. How exactly the priests were thought to channel the voice of the oak is not made clear in Homer, but there was a tradition in antiquity, first hinted at in Ovid, of rationalising the voice as the sound of the leaves rustling, which would then somehow be interpreted to produce an oracular message. ${ }^{32}$ This rationalising interpretation may have been a late accretion, but it does seem to adhere closely to the text of the Odys-

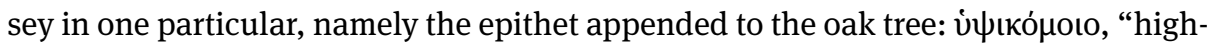
haired”. If we set Catullus' phrase loquente coma, “talkative hair”, beside Homer's

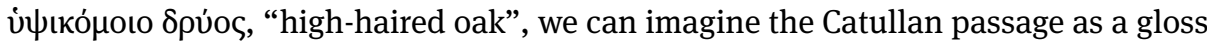
on the Homeric, 'explaining' how the oak produces its oracular utterances; but the connexion between the two passages is subtler than allusion. What they have in common, rather, is that they both pose in poetry the fundamental question of the voice raised above: is it a vital principle or a mechanical effect? If the oak's voice is nothing more than the overdetermined rustling of leaves, then the tree is merely an instrument of the breeze, with no oracular agency of its own. But if the timber of the oak or its offspring can confer the power of prophetic speech on its products, then the oak's voice is more like an inner spark than a sound effect.

Likewise, the whispering of the woods on Mt. Cytorus can on one level be considered a trick of the wind, but on another level, the adjective loquente implicitly links the phaselus' garrulity to the chattering leaves of its native forest, suggesting that its voice is a genetic property. This tacit aetiology of the boat's voice adds a further dimension to the origin-story in vv. 13-19, where we witness its transformation from tree to vessel. The phaselus' autobiography does not only anthropomorphise the boat, it reformulates the transition from tree to felled timber to boat as a process of organic development: one day he is standing tall, the next day he explores the water below with mysterious appendages which are both oars and hands, the next day he strikes out on his own. Significantly, this narrative is presented as a snippet of private experience, a secret known only to the phaselus and its place of birth, and something which

32 Ov. met. 7,629-630 (a tree seeded from Dodona); Stat. Theb. 3,475-476 and 8,201-202; cf. Parke 1967, 12-13. 
can only be transmitted to our mediator and to the passersby through the voice of the boat. The apostrophe to Amastris and Mt. Cytorus (13-14), though spoken of course in the mediator's voice, creates a sense that we are eavesdropping on an intimate conversation between the boat and its natal landscape. Just as in the nautilus epigram, therefore, the fiction of the boat's voice is bound up with the fiction of an inner life, complete with depth of experience and secrets to be divulged.

The phaselus promotes the fiction of its voice by denying its artificiality: it was not made, but born, and, in accordance with its very name, which literally refers to a kind of bean, its nature is at one with the plant matter of which it is built. However, in disavowing its artificiality, the boat paradoxically brings us closer into contact with its materiality. The 'whistle' which the phaselus-forest emits from its speaking hair is simultaneously mythological and mundane; it is both the sign of vocal presence and 'just the wind'. Both of these, moreover, can be heard in the poem itself, via the hissing alliteration saepe sibilum; and with that the imaginary depth of the voice gives way once more to the sleek surface of the text. If the sound of the boat's voice is the sound of the poem, then we cannot be so sure, to return to Svenbro's theory of inscription, whether it is the speaker of the poem who lends his voice to the boat or the other way round. Svenbro's theory requires a human voice to bestow sonorous reality on lifeless markings; but in Catullus' poem voice is a property of the secret life of things, of the environment, of rustling, swaying, creaking plant matter.

This brings us back finally to Courtney's suggestion that the speaker of the poem is to be imagined as reading out an inscription on the boat for an audience of hospites. In this scenario, the speaker's act of reading is not only an act of pulling a voice out of a mute text, but also an act of prosopopoeia. By employing the verb ait to introduce the boat's voice, the speaker occludes both his act of reading and his act of animation by eliding them with his present vocal performance. The result of this double occlusion is the production of a text which could not conceivably be inscribed anywhere. The same poet who reminds us elsewhere that a woman's words to her lover might as well be written on wind and water (Catull.70,3-4) now gives us a poem filled with wind and water, and nowhere to write, no stable surface onto which we may imagine the text inscribed. And yet, paradoxically, this mystification of the letter ends up throwing the inscribed surface more clearly into relief.

At the close of his narrative, the phaselus relates how his many adventures finally led him here "to this limpid lake" (24: hunc ad usque limpidum lacum). We are not told where this lake is, but we do know from the deictic pronoun hunc that it is here before us, in the same space occupied by the hospites and their shared hallucination of the voice of the phaselus. The adjective limpidum with its connotations of "translucent" or "see-through" belongs to the realm of visual perception, and thus with the end of the boat's story-the silencing of its voice-we have circled back to the act of viewing with which the poem began, announced by the verb videtis in the first line. If these hospites are also, as Courtney suggests, the readers of a notional inscription, then their encounter with the lake is an image of our readerly encounter with Catullus' poem, 
figured now as a visual encounter with an inscribed surface rather than an aural encounter with a revelatory vocal presence. The limpid lake, like the inscribed surface of Catullus' poem, is a shimmering veneer, but not a façade; surface and depth are indistinguishable to the eye. As a transparent body which is both surface and container, divulging all and yet revealing nothing, the lake can be taken as an emblem for the way each of these poems plays with the materiality of text, causing the inscribed surface at once to materialise and to fade from view-and this in turn reaffirms the aptness of the metaphor of textum, suggesting that not only the material but also the materiality of text is a densely woven fabric, filled with twists and turns.

\section{Bibliography}

Bruss, Jon (2010), "Ecphrasis in Fits and Starts? Down to 300 BC", in: Manuel Baumbach, Andrej

Petrovic and Ivana Petrovic (eds.), Archaic and Classical Greek Epigram, Cambridge, 385-403.

Butler, Shane (2015), The Ancient Phonograph, New York.

Chase, Cynthia (1987), “Monument and Inscription: Wordsworth's 'Lines”, in: Diacritics 17 (4), 66-77.

Connor, Steven (2000), Dumbstruck: A Cultural History of Ventriloquism, Oxford.

Courtney, Edward (1997), “Catullus' Yacht (Or was it?)”, in: The Classical Journal 92 (2), 113-122.

Davis, Gregson (2002), “Ait phaselus: The Caricature of Stylistic Inelegance in Catullus 4”, in: Materiali e discussioni per l'analisi dei testi classici 48, 111-142.

Day, Joseph (2010), Archaic Greek Epigram and Dedication: Representation and Reperformance, Cambridge.

Feeney, Denis (2013), "Representation and the Materiality of the Book in the Polymetrics", in: Ian DuQuesnay and Tony Woodman (eds.), Catullus: Poems, Books, Readers, Cambridge, 29-47.

Fitzgerald, William (1995), Catullan Provocations: Lyric Poetry and the Drama of Position (Classics and Contemporary Thought 1), Berkeley.

Fordyce, Christian (1967), Catullus, comm. by C. F., Oxford.

Frye, Northrop (1985), “Approaching the Lyric”, in: Chaviva Hošek and Patricia Parker (eds.), Lyric Poetry: Beyond New Criticism, Ithaca (NY), 31-37.

Goldhill, Simon (1994), "The Naïve and Knowing Eye: Ecphrasis and the Culture of Viewing the Hellenistic World", in: Simon Goldhill and Robin Osborne (eds.), Art and Text in Ancient Greek Culture, Cambridge, 197-223.

Gow, Andrew/Page, Denys (1965), The Greek Anthology: Hellenistic Epigrams, 2 vol., ed. by A. G. and D. P., Cambridge.

Gutzwiller, Kathryn (2002), “Art's Echo: The Tradition of Hellenistic Ecphrastic Epigram”, in: Annette Harder, Remco Reguit and Gerry Wakker (eds.), Hellenistic Epigrams (Hellenistica Groningana 6), Leuven, 85-112.

Gutzwiller, Kathryn (1992), “The Nautilus, the Halycon, and Selenaia: Callimachus's Epigram 5 Pf. = 14 G.-P.", in: Classical Antiquity 11 (2), 194-209.

Hardie, Alex (1983), Statius and the Silvae: Poets, Patrons, and Epideixis in the Graeco-Roman World (ARCA Classical and Medieval Texts, Papers and Monographs 9), Liverpool.

Höschele, Regina (2007), “The Travelling Reader: Journeys Through Ancient Epigram Books”, in: Transactions of the American Philological Association 137 (2), 333-369.

Lauxtermann, Marc (1988), “What is an Epidectic Epigram?”, in: Mnemosyne 51 (5), 525-537. 
Massaro, Matteo (2010), “Il phaselus di Catullo e la nave Argo di Apollonio”, Materiali e discussioni per l'analisi dei testi classici 64, 9-42.

Männlein-Robert, Irmgard (2007), “Epigrams on Art: Voice and Voicelessness in Hellenistic Epigram”, in: Peter Bing and Jon Bruss (eds.), Brill's Companion to Hellenistic Epigram, Leiden, 251-271.

Mette, Hans (1962), “Catull Carm. 4”, in: Rheinisches Museum für Philologie 105 (2), 153-157.

Page, Denys L., Further Greek Epigrams, ed. by D. L. P., Cambridge.

Parke, Herbert (1967), The Oracles of Zeus: Dodona, Olympia, Ammon, Oxford.

Powley, Edward (1931), A Hundred Years of English Poetry, Cambridge.

Reddy, Michael (19932), "The Conduit Metaphor: A Case of Frame Conflict in our Language About Language", in: Andrew Ortony (ed.), Metaphor and Thought, Cambridge, 164-201.

Schmitz, Thomas (2010), “Epigrammatic Communication in Callimachus' Epigrams”, in: Greek, Roman and Byzantine Studies 50 (3), 370-390.

Sens, Alexander (2002), "An Ecphrastic Pair: Asclepiades AP 12.75 and Asclepiades or Posidippus API 68", in: The Classical Journal 97 (3), 249-262.

Svenbro, Jesper (1993), Phrasikleia: An Anthropology of Reading in Ancient Greece, trans. by Janet Lloyd, Ithaca (NY).

Thomson, Douglas (1997), Catullus, ed. and comm. by D. T. (Phoenix. Supplementary Volume 34), Toronto.

Tueller, Michael (2010), “The Passer-by in Archaic and Classical Epigram”, in: Baumbach/ Petrovic/ Petrovic 2010, 42-60.

Wachter, Rudolph (2010), “The Origin of Epigrams on 'Speaking Objects”, in: Manuel Baumbach, Andrej Petrovic and Ivana Petrovic (eds.), Archaic and Classical Greek Epigram, Cambridge, 250-260.

Walsh, George (1991), “Callimachean Passages: The Rhetoric of Epitaph in Epigram”, in: Arethusa 24 (1), 77-105. 
